\title{
A relational approach to heterodox versus orthodox positions in contemporary cultural policy debates
}

Mehdi Arfaoui ${ }^{1 凶}$

This article examines the categories of orthodoxy and heterodoxy in regards to their use by many authors to position themselves within a research field. By doing so, it attempts to offer original methods for systematically addressing the morphology of a specific field of research. Particularly in economics, establishing one's position in a field of research is often portrayed in terms of their alignment to orthodox or heterodox perspectives. However, this positioning within categories of "orthodoxy" or "heterodoxy" generally contain implicit political assumptions that are infrequently made explicit. The use of these categories typically implies dominant and dominated positions in a given research field, as well as suggests conformist versus nonconformist approaches to mainstream policy. Consequently, as these overburdened categories are rarely unpacked and explained by those who rely on them, delineating an orthodox versus heterodox viewpoint is nearly impossible. The hypothesis underlining this paper is that, more than the content of the academic production itself, belonging to the heterodoxy or the orthodoxy can be explained through the interpretation by the actors of their own position, as well as the type of relationship they cultivate in the field. The study is based on the exploration of more than 3000 pages of academic production on the topic of cultural policy, following an academic debate from 2000 onward between 11 different authors from various disciplines on the "creative industries turn of cultural policies". After providing background on the case study as well as a presentation of the research sample and methodology, the paper explores whether a more granular interpretation of orthodox and heterodox positions in a research field can be described. Firstly, a discourse analysis will show how orthodox versus heterodox positions can be depicted through the subjective interpretations by authors of their own position in the field. In this debate, selfproclaimed heterodox-positioned authors tend to represent themselves as a minority in their research field, having difficulty accessing and influencing political decision-making processes. In contrast, orthodox-positioned authors tend to perceive their academic production as unpolitical and their analysis as objective and pragmatic in opposition to "militant" heterodox research. This first "subjective" analysis is followed by illustrating how this binary can be described "objectively" by systemizing citation links between the authors. The demonstration allows a clear segregation between orthodox and heterodox positions, but also displays significant variations in the relationship structure between both fields. The work concludes on

${ }^{1}$ EHESS-CEMS, Paris, France. ${ }^{\bowtie}$ email: mehdi@arfaoui.net 
the analytical possibilities brought by this relational approach. More importantly, this paper concludes that scientific dominance or political influence need not only to be explained as radical epistemological differences invoked by heterodox and orthodox positionality, but also by the interdependence of the authors belonging to these categories. Overall, this paper aims to draw attention to a potential research agenda that uses a more dynamic understanding and categorization of heterodoxy and orthodoxy. 


\section{Introduction}

his article questions the possibility to simultaneously generalize and systematize the use of "orthodoxy" and "heterodoxy" as analytical categories when studying fields of research or discursive formation. On the one hand, describing the structure of an academic controversy-namely the "creative industries turn" of cultural policy debate,-it aims to test the relevance of the orthodox versus heterodox categorization to describe academic debates in general. On the other hand, the article seeks to investigate what makes it possible to more systematically define a scientific positioning as orthodox or heterodox.

The categorization of "orthodoxy" versus "heterodoxy" has become a common way to describe networks of researchers and theories in the field of economics. However, the significance of this distinction goes well beyond the field of economics or cultural policy studies as far as we are concerned. From a constructivist point a view, it could be stated that any field of symbolic production may be observed through this distinction (Bourdieu, 2001, 1994): apart from the case of religion (Lake, 2001; Simon and Langer, 2008; Wilson, 2009) and ritual practices (Sangren, 1987), I can cite other academic fields such as sociology (Bernard, 1935; Calhoun and Antwerpen, 2007), political science (Gunnel, 2006), organizational management (Balmer et al., 2016), medical practice (Wardwell, 1972) or even heritage studies (Lixinski, 2015). This categorization generally contains implicit political assumptions that are infrequently made explicit. The use of these categories typically implies dominant and dominated positions in a given research field, as well as suggests conformist versus nonconformist approaches to mainstream policy. As these overburdened categories are rarely unpacked and explained by those who rely on them, it appears difficult to objectively delineate orthodox versus heterodox positions. Moreover, this categorization often hinders the multiplicity of institutions involved in determining the inclusion in either side of the field (Bögenhold, 2010) as well as the potential circulation of actors and ideas from heterodoxy to orthodoxy and vice versa (Lee and Elsner, 2008; Carpintero, 2013).

To prevent ourselves from those pitfalls, my intention in this article will be to avoid defining the orthodox versus heterodox position of researchers, as it is usually the case in the literature, on the basis of the theories developed by those very researchers. As Glötzl and Aigner argue, "while the paradigmatic structure of the discourse in economics has received much attention, much of the literature has relied solely on a verbal and (to a lesser extent) statistical description. So far, only a few attempts have been made to empirically investigate whether economics follows an 'orthodox core-heterodox periphery' pattern" (Glötzl and Aigner, 2018). Instead, I will use descriptions of the literature produced by the research field to illustrate the variation in relationship structure between both parts of the field. I will do so by depicting the subjective interpretations by the authors of their own position in the field, as well by objectively modeling citation links between the authors.

If economics have a coherent and established existence as a discipline, the field that will constitute my main object here-that of cultural policy studies - represents more of a discursive formation. Indeed, cultural policy studies integrate researchers coming from different disciplines (arts administration, economics, history, media studies, sociology, etc.). This juxtaposition-inseparation of different disciplinary traditions makes it an inconsistent group of researchers that would rather be observed as a multi-disciplinary nexus (Bennett, 2004).

The remainder of the paper is structured as follows: in the section "The "creative industries turn" of cultural policy: a case study", I will first present the case study on the "creative industries turn" debate, an academic controversy that follows the reform of cultural policies in many countries (most notably Great-Britain and Australia). This debate opposes two sides: the first one is favorable to the "creative industries turn", i.e. favorable to the redefinition of cultural policies around the notions of creative industries and creative economy; the second one is critical to the "creative industries turn", which they present as a neoliberal reform of cultural policy. In section "Sample selection and methodology", i.e. the third section of the article, I will present the research sample as well as my methodology. The study is based on the exploration of more than 3000 pages of academic production on the topic of cultural policy, following an academic debate from 2000 onward between 11 different authors from various disciplines on the "creative industries turn" of cultural policies. In section "Results" the results will then be presented in two parts: I first show that self-proclaimed heterodoxpositioned authors tend to represent themselves as a minority in their research field, having difficulty accessing and influencing political decision-making processes. In contrast, orthodoxpositioned authors tend to perceive their academic production as unpolitical and their analysis as objective and pragmatic in opposition to "militant" heterodox research. This first "subjective" analysis is followed by illustrating how this binary can be described "objectively" by systemizing citation links between the authors. This demonstration allows a clear segregation between orthodox and heterodox positions, but also displays significant variations in the relationship structure between both parts of the field. In the section "Conclusion" at last, this work concludes on the analytical possibilities brought by this relational approach. More importantly, this paper concludes that scientific dominance or political influence need not only be explained as radical epistemological differences invoked by heterodox and orthodox positionality, but also by the interdependence of the authors belonging to these categories. Overall, this paper aims to draw attention to a potential research agenda that uses a more dynamic understanding and categorization of heterodoxy and orthodoxy.

The "creative industries turn" of cultural policy: a case study This article is the result of a reflection carried out during my $\mathrm{Ph}$. D. thesis on the metamorphosis of cultural policy at the level of the European Union. I speak of "metamorphosis" because in recent decades, the conceptual frameworks that traditionally permitted to justify public spending for culture have progressively suffered from criticism and disqualification, and new conceptual frameworks needed to be developed by researchers and experts in coordination with politicians to define new forms of justification. ${ }^{1}$ As shown in Tony Bennett's Culture: A Reformer's Science, intellectuals indeed play an effective role in the (re)organization of contemporary cultural policies (Bennett, 1998).

I show in my thesis (Arfaoui, 2019) that, until the 1980s, a prevailing conceptual dichotomy opposing: on the one hand, an elitist conception of cultural policy according to which the public authorities had an educational role, supporting "high-brow" culture and giving people the Kantian "capacity to judge"; and, on the other hand, an industrial conception through which public authorities play the role of sponsors of a market in which cultural enterprises sought to gain access to the largest segment of consumers (see Table 1).

This conceptual opposition between "cultivated culture" and "mass culture" still structures many discussions about the status of culture as well as the role of the State towards culture in contemporary societies today. However, from the 1970s and 1980s onwards, both of these conceptions entered into crisis. Critiques that reach the industrial conception and those that 


\begin{tabular}{lll|}
$\begin{array}{l}\text { Table } 1 \text { Traditional conceptions of cultural policy (prevailing } \\
\text { from 1950 to 1970). }\end{array}$ \\
& Industrial conception & Elitist conception \\
\hline Status of culture & Commodity & Piece of art \\
Valued character & Consumer & Artist, genius \\
Valued properties & Popular, ordinary & Universal, authentic \\
Valued & Entertainment, & Distinction, \\
interactions & enjoyment & hierarchization \\
Role of the State & Sponsor of industrial & Instructor, educator \\
& interests & \\
\hline
\end{tabular}

reach the elitist conception differ, but concur on a critique of the maintenance, through cultural policy in particular, of bourgeois domination (whether it is a State bourgeoisie or an industrial bourgeoisie). On the whole, they denounce three corollaries of these conceptions that contribute to the maintenance of this domination: first, the finality associated with culture ("profit" on the one hand, "cultural propaganda" on the other); second, the effect on cultural production ("standardization" on the one hand, "the exclusion of popular culture" on the other); third, the effect on the publics of culture ("the prolongation of the alienation of the worker" on the one hand, and "symbolic violence" on the other).

In the 1980s, and then exacerbated in the 1990s, many discourses and ideas emerged to respond to one or the other of these criticisms, opening the way to new conceptions. The specificity of these discourses is that they repeatedly mobilize the notion of "creativity" and the untapped "creative potential" of the cultural sector. Prime examples include the statement; in 1997, of the newly elect Prime Minister of Great Britain, Tony Blair, explaining that he wanted to use his election to create a break with the conservative policies pursued by past political parties. According to him, while "our future depends on creativity", the arts and culture had for too long been "sidelined" of "sacralized". In order to grasp the "creative potential" on which the future of European nations depended, the Labor Party manifesto suggested that the new millennium should be an opportunity for a new "dynamic" approach to art and culture, viewing creativity as an "intellectual capital", and putting the work of arts and cultural organizations at the center of a knowledgebased economic system.

The so-called "creative industries turn" is the metaphorical name given to this period of redefinition of cultural policy in many countries. It happened with the joint development of new public instruments to ensure a better "diffusion of cultural creativity" in the rest of the economy (new public-private partnerships, managerialization of work in cultural organizations, integration of economic and "social impact" indicators (Hesmondhalgh et al., 2014)), as well as a new conception of cultural policy, giving the State the role of an investor in the processes and infrastructures that make it possible to establish arts and culture as a source of human capital and innovation. From the 1990s onwards, several governments-starting with the British and Australian Labor Parties-worked with economists to theorize the concept of the "creative economy" and to rethink the place of "culture" in the productive economy. The cultural economist Justin O'Connor points to the ease with which the principles of the creative economy and creative industries subsequently seemed to adapt to national contexts, becoming a "frame of reference" not only in Britain (Hesmondhalgh et al., 2014), but also in the rest of Europe (O'Connor, 2007) and the world-in South America and South east Asia in particular (Wang, 2016).

In the following years, the "creative industries turn" became an important object of research for scholars worldwide. Researchers
Table 2 Modern conceptions of cultural policy (prevailing from 1980 to 2010).

\begin{tabular}{lll} 
& Ecological conception & Innovative conception \\
\hline Status of culture & Plural ecology & Input, creative capital \\
$\begin{array}{l}\text { Valued character } \\
\text { Valued properties }\end{array}$ & Citizen, civil society & Entrepreneur \\
Valued interactions & Local, & Novelty, future \\
& sharing, & Symbiosis, hybridization \\
& debating & \\
Role of the State & Local community & Investor \\
\hline
\end{tabular}

in social sciences-particularly in economics, management, political science, sociology and information and communication - simultaneously entered a series of disputes about the "creative industries turn" of cultural policies (Flew and Cunningham, 2010; Harney, 2010; Banks and O'Connor, 2017). While dominated by an academic production favorable to the "creative industries turn", the field of study on the reform of cultural policy appeared divided and conducive to many debates. The dispute, continuing to the present day, opposed, researchers in favor of these reforms to critical researchers to whom the "creative industries turn" rather represents a "neoliberal turn". According to those critical researchers, there are economic and social inequalities that bias the entrepreneurial game of the alleged "creative economy". The main transformation to be carried out concerning cultural policies should therefore consist in making those inequalities visible through the recognition of the plurality of cultural practices (Oakley, 2006; Schlesinger, 2013; Hesmondhalgh and Banks, 2009).

The analysis of the normative literature produced by those researchers thus allows us to take this dispute as the locus of a discussion on the "right way" to respond to traditional critiques of cultural policy (see Table 2). As a matter of fact, the traditional dichotomy seemed to be gradually substituted during this period by a "modern" dichotomy opposing: on the one hand, an innovative conception in which the market no longer assesses the desirability of cultural products, but the capacity of the cultural field to generate "innovation" and to be able to combine its productions in symbiosis with products from other sectors; and, on the other hand, an ecological conception, often exercised at the level of local communities whose action is directed towards sharing, debating and making "common".

In the remainder of this article, I explore to what extent the opposition between defenders of the innovative conception and defenders of the ecological conception can be described as an opposition between orthodox researchers and heterodox researchers. In the next sections, I will first detail the characteristics of the sample and my methodology (Table 3), then show that, apart from an analysis of the content of their theories, the categorization of those researchers between orthodoxy and heterodoxy can be determined both by noting the adjectives that they use to describe their reciprocal position in the field and by systematically analyzing the intercitation links between these authors (Table 4).

\section{Sample selection and methodology}

I cannot claim to have a complete treatment of the data, texts and authors of the literature dealing with the creative economy, creative industries, or the "creative industries turn" of cultural policies. Rather than claiming to be exhaustive, I have chosen to produce a systematic analysis on a small sample representative of the network of actors participating in this debate. The material is 
Table 3 Sample of researchers studied by position.

\section{Orthodox cluster}

\begin{tabular}{|c|c|c|c|c|c|}
\hline \multicolumn{2}{|l|}{ Name } & \multicolumn{3}{|l|}{ Academic position } & Country \\
\hline \multicolumn{2}{|c|}{ CAVES Richard E. } & \multicolumn{3}{|c|}{$\begin{array}{l}\text { Emeritus Professor of Economics, } \\
\text { Harvard University (since 2003). }\end{array}$} & US \\
\hline \multicolumn{2}{|c|}{ CUnNINGHAM Stuart } & \multicolumn{3}{|c|}{$\begin{array}{l}\text { Professor of Media and } \\
\text { Communications, Queensland } \\
\text { University of Technology (since 1997). }\end{array}$} & AUS \\
\hline \multicolumn{2}{|l|}{ FLORIDA Richard } & \multicolumn{3}{|c|}{$\begin{array}{l}\text { Professor of Economic Analysis and } \\
\text { Policy, the Rotman School of } \\
\text { Management, University of Toronto } \\
\text { (since 2007). }\end{array}$} & US \\
\hline \multicolumn{2}{|l|}{ HowkINS John } & \multicolumn{3}{|c|}{$\begin{array}{l}\text { Vice Dean and Visiting Professor, the } \\
\text { Shanghai School of Creativity, } \\
\text { Shanghai Theatre Academy } \\
\text { (since 2006). }\end{array}$} & UK \\
\hline \multicolumn{2}{|l|}{ ThrosBY David } & \multicolumn{3}{|c|}{$\begin{array}{l}\text { Distinguished Professor of Economics, } \\
\text { Macquarie University (since 1974). }\end{array}$} & AUS \\
\hline \multicolumn{6}{|c|}{ Table 4 Intercitation links configuration grid. } \\
\hline $\begin{array}{l}\text { Reason for } \\
\text { the quotation }\end{array}$ & \multicolumn{2}{|c|}{$\begin{array}{l}\text { Theoretical proximity } \\
\text { (calculated attraction) }\end{array}$} & $\begin{array}{l}\text { Value } \\
\text { configured } \\
\text { on Gephi }\end{array}$ & \multicolumn{2}{|c|}{$\begin{array}{l}\text { Graphical } \\
\text { representation }\end{array}$} \\
\hline A critical B & \multicolumn{2}{|c|}{ Low } & Intensity 1 & & \\
\hline A quotes B & \multicolumn{2}{|c|}{ Neutral } & Intensity 10 & & \\
\hline A supports B & \multicolumn{2}{|c|}{ Strong } & Intensity 30 & & \\
\hline
\end{tabular}

thus exclusively based on the content of books and articles written by eleven English-speaking researchers represented during this dispute, whose positions were sufficiently clear to give us a photograph that is conducive to the formalization of their conceptions.

Since this survey originates from doctoral interrogations on the shape taken by the "creative industries turn" at the European Union level, to build my sample I first focused on two reports commissioned by the European Commission (KEA, 2006, 2009), both representative of a moment of explicit reconceptualization of the European cultural policy around the concepts of economy and creative industries. After collecting a list of authors and bibliographic references, I mobilized academic search engines-in particular Google Scholar-to identify a "second level" bibliography referring to the elements of my first list. After having identified more than thirty authors and more than a hundred bibliographic references, my work to delimit the sample consisted in making several choices. First of all, I focused on researchers publishing in English: even if the dispute that interests us may have spread for example in the French-speaking academic spheres - notably through Benghozi and Paris (2016) who appear as orthodox, or Miège et al. (2013) and Bouquillion (2009) who rather appear as heterodox-it initially appears to be significant between English-speaking authors (British, American, and Australian). Those authors call each other by their names and answer
Heterodox cluster

$\begin{array}{lll}\text { Name } & \text { Academic position } & \text { Country }\end{array}$

Hesmondhalgh David Professor of Media, Music and Culture, School of Media and Communication, University of Leeds (since 2007).

Garnham Nicholas Emeritus Professor of Communications Policy, University of Westminster (since 2002)

Honorary Professor of Cultural Analysis, Social Sciences Departement, University of Loughborough (since 2002).

Professor of Cultural Policy, School of Culture \& Creative Arts, University of Glasgow (since 2018).

PRATT Andy C.

Professor of Cultural Economy, Centre for Culture and the Creative Industries, City University London (since 2013).

Professor of Cultural Policy, School of

UK

Culture \& Creative Arts, University of Glasgow (from 2007 to 2013). Currently Visiting Professor of Media and Communications at the LSE. each other- something that only happens very occasionally between English-speaking and French-speaking authors. This resonates with the idea that there are celebrity logics in the academic field, producing strong citation inequalities between English-speaking scholars and others (Angermuller and Hamann, 2019). The upcoming results must then be appreciated in consideration of the fact that significantly different patterns could have been found using a non-Anglophone debate as my empirical source. Secondly, an intensive preliminary review allowed me to observe that some authors appear recurrently and seem to catalyze either criticisms or, on the contrary, the rallying of some authors. As such, numerous round trips between the creation of this list and my readings have enabled me to refine my choice and arrive at a sample that I consider balanced. A systematic comparison with other literature reviews also allowed us to confirm that this compromise made sense to other readers of this literature. $^{2}$ Third, the authors I have chosen are academics, most of whose work is subject to the evaluation processes of the research community. As almost all the participants in this dispute had their academic background mixed with an activity as a practitioner or consultant in the world of art, cultural industries or public policy in general, it seemed irrelevant to restrict my choice to pure academics alone. In order to preserve the coherence necessary for my analysis, I nevertheless chose to exclude profiles that did not hold any position in the academic world. ${ }^{3}$

In a nutshell, this sample represents, as much as possible, the heart of the network of English-speaking researchers involved in the dispute, either because they are very active in the dispute, or because they are regularly cited as a reference (both by critics and supporters), or because they are both very active and regularly appear as references.

The distribution of actors' position in the dispute between heterodoxy and orthodoxy could be analyzed from this sample as being expressed at two levels that I describe below: in terms of the subjective expression of the actors in this field and in terms of the intercitation links that structure this dispute. To get to these results, I selected, from the bibliography of those 11 researchers, 


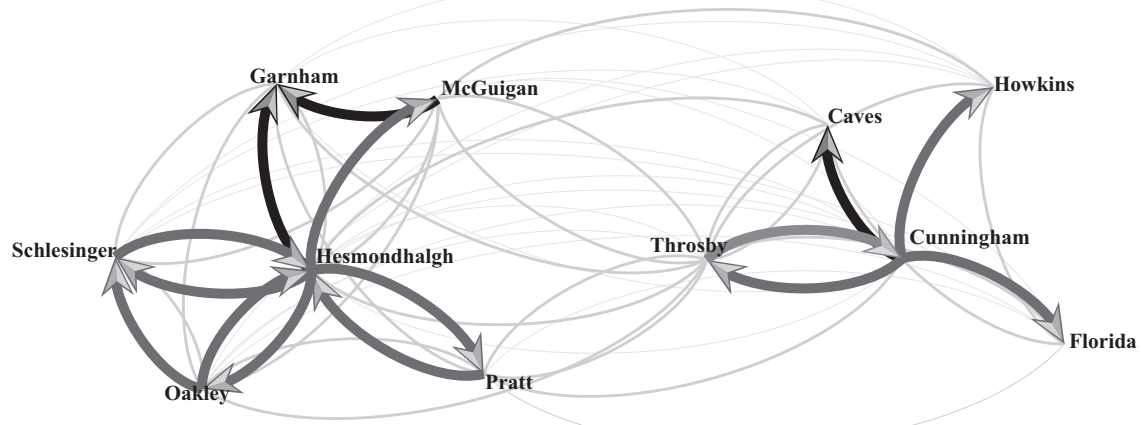

Fig. 1 Representation of the network. Made with Gephi to show the intensity and direction of intercitation links.

32 books, chapters or articles published in relation to the "creative industries turn" (see Appendix).

While browsing through all these texts, I first systematically listed-with the help of the qualitative data analysis software ATLAS.ti-the parts of the literature through which the actors express themselves on their subjective position in the field: i.e. the way in which the researchers qualify the position of other researchers in the field and describe their own position in the field.

I then sought to systematically list all the mutual citations between researchers with the intention of modeling the network of this dispute. I identified and noted in Gephi-a network analysis and visualization software-all 183 mutual citations between these 11 authors. Still using the Gephi software, I configured three levels of intensity for those links, illustrating the theoretical proximity between these researchers. The levels of intensity have the effect of physically bringing the points of the network (i.e. the researchers) closer or further away (Fig. 1):

- Low attraction (intensity 1) is when researcher A explicitly criticizes researcher B;

- Neutral attraction (10 intensity) is when researcher A quotes researcher B;

- High attraction (intensity 30) is when researcher A explicitly supports researcher $\mathrm{B}$.

From this grid, I manually ranked each of 183 citations to match a value (see Appendix). Ultimately, Gephi has been configured to give priority to quotations that support or criticize an author, over neutral quotations. Therefore, when author A quotes author B several times, the general value of the intercitation link (from A to B) has been marked with the most extreme value (1 or 30) among the citations identified. For example, if A cites B once to criticize it and once in a neutral way, the value of the intercitation link I keep is 1 (A criticizes B) and not 10 (A cites B). Note: This is made possible by the fact that, in the analysis of my sample, I have never observed A both criticizing and supporting B.

\section{Results}

Following the analysis I was able to make of this sample, a distribution of the actors in the dispute between heterodoxy and orthodoxy was expressed at, at least, two levels that I will describe here: at the subjective level of the actors in this field, and at the objective level of the structure of this dispute. The first level is associated with the subjective expression-by the authors themselves-of their position in the field of cultural policy studies (section "Subjective positioning"), the second level is related to their objective interactions in the field of research (section "Objectification of positions").

\begin{tabular}{lll|} 
Table 5 Perception by researcher position. & \\
& $\begin{array}{l}\text { Heterodox } \\
\text { researchers }\end{array}$ & Orthodox researchers \\
\hline $\begin{array}{l}\text { Perception of the } \\
\text { opponent's position }\end{array}$ & $\begin{array}{l}\text { Accommodated by } \\
\text { neoliberalism, } \\
\text { promoter of the } \\
\text { dominant ideology }\end{array}$ & $\begin{array}{l}\text { Politicized, militant, } \\
\text { non-pragmatic }\end{array}$ \\
$\begin{array}{l}\text { Perception of their own } \\
\text { position }\end{array}$ & $\begin{array}{l}\text { Marginalized, } \\
\text { resistant }\end{array}$ & $\begin{array}{l}\text { Unpoliticized, } \\
\text { pragmatic }\end{array}$ \\
\hline
\end{tabular}

Subjective positioning. The antagonism between the positions in this dispute is first of all expressed by the authors themselves. All the researchers I read recognized the issues and interrogations raised by political reforms for a "creative industries turn" of cultural policies (Flew and Cunningham, 2010; Pratt, 2005; Schlesinger, 2009; Banks and O'Connor, 2017; O'Connor, 2007). However, they do not have the same tendency to corroborate and support or, conversely, to criticize the reforms developed by decision-makers. Depending on their support or rejection of institutional discourse, the authors are positioned either on the side of "governance" or on the side of "criticism" (see Table 5).

In this section, I show that researchers positioned on the orthodox side define their point of view as largely accepted and consider their position as "non-politicized" and "pragmatic", unlike heterodox researchers who are perceived as "militant", "political" and too critical to help support public policy formulation. On the other hand, researchers positioned on the heterodox side seek to discuss the categories used by the orthodox and propose alternative readings. They perceive themselves as marginalized and resistant to the "dominant neoliberal ideology" of which they accuse orthodox scholars of being naive promoters.

Perception of the opponent's position. According to heterodox researchers, the "creative industries turn" of cultural policies is essentially linked to a process of "neoliberalization of culture". For example, Jim McGuigan, Honorary Professor of Cultural Analysis at Loughborough University, published an article entitled "Neo-Liberalism, Culture and Policy" in 2005, and more recently a book entitled Neoliberal culture (2016). As he says in the introduction to his book: "It is vital to examine the impact of neoliberalism on culture and politics, as well as adherence to and resistance to it". Most of this criticisms of authors supporting creative industries are therefore aimed at denouncing their attachment to a "dominant ideology". David Hesmondhalgh is probably the most vehement in this regard. Professor of Media studies at the University of Leeds, he regrets the "general adherence" to the term "creative industries" and the "degree of 
accommodation" to neoliberalism that this new discourse shows. He affirms the need to pursue the critique of capitalism initiated by the theorists of the Frankfurt School: "My main claims are that the term 'creative industries' represents a refusal of the forms of critical analysis associated with the cultural industries approach, and that unqualified use of the former now signals a considerable degree of accommodation with neoliberalism" (Hesmondhalgh, 2008, p. 552). Similarly, Philip Schlesinger, Professor of Cultural Policies at the University of Glasgow, is the most explicit researcher in describing what he perceives as an "orthodoxy", a discourse presented to everyone as obvious. In an article written in 2016, entitled "The creative economy: invention of a global orthodoxy", he explains that he was "increasingly struck by how difficult it is not to talk approvingly and largely uncritically about the 'creative industries' and the 'creative economy'. These tropes presently dominate policy debate and media discussion about culture. This discursive dominance has become both a conceptual and practical obstacle to thinking afresh" (Schlesinger 2016, p. 73).

Among the orthodox scholars, on the other hand, this reference to "neoliberalism" as a term to describe the creative shift and the redefinition of cultural policies is poorly perceived and strongly questioned. Stuart Cunningham, Professor of Media and Communications at Queensland University of Technology, sees the concept of neoliberalism as an activist term which legitimacy in academic debates must be questioned. According to him, "neoliberalism as a concept emerged in the late 1990s and early 2000s as an omnibus term used by activists to critique and protest institutions and forums associated with globalization" (Flew and Cunningham 2010, p. 6). Stuart Cunningham views critical researchers as opposed to public action and therefore unwilling to contribute to it. Thus, by explicitly targeting the heterodox authors mentioned above, he argues that "the gap between [the reception of the creative industries ideas] in such circles internationally and at many levels (national, state, regional, intergovernmental), and the depth of opposition to it amongst critical scholarship suggests it as a textbook case of the disabling gap between policy and critique" (Cunningham 2009, p. 375).

Perception of their own position. The perception of the opposing party-adherence to the "neoliberal doxa" according to the heterodox and "infertile criticism" according to the orthodox-corresponds to a self-representation of the researchers of their position in the field.

Orthodox authors, on the one hand, observe their position as "neutral", "objective" and "pragmatic". For example, Stuart Cunningham, in contrast to "critical" approaches, claims to be working to produce a "non-political" definition of the creative industries that is not characterized by "the concerns of aggrieved parties or corporatism" (Cunningham et al. 2008, p. 176). Richard Florida, Professor of Economic Analysis and Policy at the Rotman School of Management in Toronto, has the same desire to declare himself "politically independent", stating that he "voted and worked for Democrats, Republicans and Independents". He says that what unites his research team is "not a political agenda, but our common determination to identify the factors that lead to economic development and raise living standards" (Florida, 2002).

Unlike orthodox scholars, heterodox researchers claim not only the critical part of their work, but also the intrinsically political dimension of public policy choices in general. Jim McGuigan, in particular, puts dispute and criticism "at the heart" of his analysis of any political reform (McGuigan, 2016). For the latter, the term "cultural policy" should no longer be used: "the politics of culture' acknowledges politics as a power struggle, a reality that is obscured by a neutralizing usage of "cultural policy"' (McGuigan
2016, p. 1). According to these researchers, this "openly critical" position goes hand in hand with a form of marginalization and minoration of their discourse in front of the "dominant" orthodox discourse. Philipp Schlesinger explains in particular the difficulty of taking on a critical role while maintaining an important and influential position in public policy (Schlesinger, 2013). In the heart of an article in which he reviews his career, both as a researcher and a "critical" consultant, he describes his experience as "marginalized" against a dominant, orthodox, official and expert group of actors: "it is a matter of flooding the market with an ideology so as to crowd out or marginalize alternatives" (Schlesinger, 2016, p. 75). David Hesmondhalgh and Jim McGuigan also use the lexicon of "domination" to describe the theoretical approaches (Hesmondhalgh, 2008) and political rationalities (McGuigan, 2005) they face. Yet all authors, even the most critical, give their work the status of a direct contribution to public policy in their country. Kate Oakley, Professor of Cultural Policy at the University of Glasgow, goes so far as to argue that the effectiveness of cultural policies depends more on those who contribute to the work of "building evidence in the long term" than on those who "influence opinion, meet the powerful, and have[their] names on publications" (Oakley, 2004, p. 71). Heterodox researchers then opt for different strategies to "stay in the game": some try to distinguish themselves as a "reasonable" alternative (Schlesinger, 2013), others adopt a more radical and visible position at the risk of withdrawing from participation in public policies (McGuigan, 2016).

As we have seen, two positions towards "creative" reforms can be defined on the basis of the authors' subjective representations. In the next section, I illustrate how the objective analysis of their relationship and visibility in the academic field tends to confirm the existence of these two positions in the dispute.

Objectification of positions. The distinction between orthodox and heterodox researchers also emerges from the systematic analysis of the intercitation links between these researchers. To show this, I have proceeded, inspired by sociolinguistic methods (Rinck, 2010), to set up a representation of a network illustrating these "links". I call "intercitation links" the way in which these researchers quote each other's work during the dispute, paying attention to the reason for the quote. We are indeed interested in knowing whether researchers quote each other in order to criticize, support the comments of another researcher or simply to point out the existence of his or her work. Starting from what the citations reveal about the relationships between researchers, I show structural differences between the orthodox and heterodox clusters of my sample.

In particular, I show in this section that the intercitation relationships between orthodox scholars reveal an individualization of careers and a phenomenon of "superstar" (Rosen, 1981) or a "celebrity logic" proper to many academic fields (Angermuller and Hamann, 2019): some orthodox scholars are widely cited while they rarely mention their peers, whereas the least cited orthodox scholars attempt to engage in disputes that make them visible. In contrast, heterodox researchers opt for reciprocal intercitation strategies that allow them to find legitimacy as a group in front of what they perceive as an orthodoxy. The reference to orthodox content thus appears to be a mandatory point of passage for heterodox researchers, while the opposite is not always true.

Polarization and intercitation. The purpose of modeling the network of the dispute is to take into account the relationships that seem to structure this group of authors. The first observation that can be made at a glance concerns the polarization of the 


\begin{tabular}{|lll|}
\hline $\begin{array}{l}\text { Table } 6 \text { Great passive and small active, a specificity of the } \\
\text { orthodox cluster. }\end{array}$ & $\begin{array}{l}\text { Great passive } \\
\text { (i.e. Caves, Florida) }\end{array}$ & $\begin{array}{l}\text { Small active } \\
\text { (i.e. } \\
\text { Cunningham) }\end{array}$ \\
\hline $\begin{array}{l}\text { Peer Citation } \\
\text { Quotations by } \\
\text { heterodox people } \\
\text { Quote to peers } \\
\text { Quote to the heterodox }\end{array}$ & $\begin{array}{l}\text { Cited } \\
\text { Criticized } \\
\text { Rarely cited } \\
\text { Does not respond to } \\
\text { criticism }\end{array}$ & $\begin{array}{l}\text { Rarely cited } \\
\text { Criticized }\end{array}$ \\
\hline
\end{tabular}

network. There is a clear separation between one cluster and the other, which makes it possible to observe both the level of attraction (support) within a cluster and repulsion (criticism) between the two clusters. Paying attention, we can also observe that the heterodox cluster does not have the same "shape" as the orthodox cluster (see Fig. 3). This distinction suggests several things about the organization within a cluster. The shape of the heterodox cluster illustrates frequent citations of mutual support (intensity 30) between the authors of the same cluster. On the other hand, the build of the orthodox cluster shows less frequent and rarely reciprocal citations of mutual support between the authors. The shape of the orthodox cluster can be explained in particular by the presence of what I call authors of great passive and small active types (see Table 6).

The great passive type, on the one hand, corresponds to orthodox authors who are frequently quoted and criticized, but never respond to criticism and rarely cite their peers from the same cluster. In my sample, Florida and Caves are examples of great passive authors. Of the 11 authors listed, their works are the most frequently used as references, most notably their respective books: The rise of the creative class (Florida, 2002) and Creative Industries: Contracts between Art and Commerce (Caves, 2000). ${ }^{4}$ These books and their authors are systematically highlighted in discourses on the "creative industries turn", both in academic literature and in institutional and grey literature. For example, Florida's name is cited 21 times in a major study commissioned by the European Commission in 2009 (KEA, 2009) and cited 11 times in UNESCO's Creativity economy report (UNCTAD, 2008). The name of Caves is also mentioned 9 times in this last report. The "scientific impact indicators" such as the "h-Index" or citation indicators provide us with a superficial, but eloquent overview that confirms the significant circulation of the work of these authors (see Fig. 2).

Although highly cited, Richard Florida and Richard E. Caves themselves rarely mention the authors of the cluster to which they belong (see Fig. 3). Similarly, strongly criticized by authors of the heterodox cluster (Florida in particular is regularly criticized by five of the six heterodox scholars, Howkins by four and Caves by two) (see Fig. 4), these authors do not respond to criticism (Florida, Howkins, and Caves do not criticize members of the heterodox cluster). Their relationship to the field therefore remains essentially unilateral and passive.

The position of small active within the orthodox cluster appears to be the opposite of the position of great passive since it implies to strongly support researchers from the same cluster, while being poorly supported by them in return. The small active, represented here by Stuart Cunningham, is also criticized by the heterodox cluster, but, unlike the great passive scholars, he responds and produces many criticisms in return (see Fig. 4). He cites other researchers, whether from the same cluster to support their positions (he supports the positions of the other four

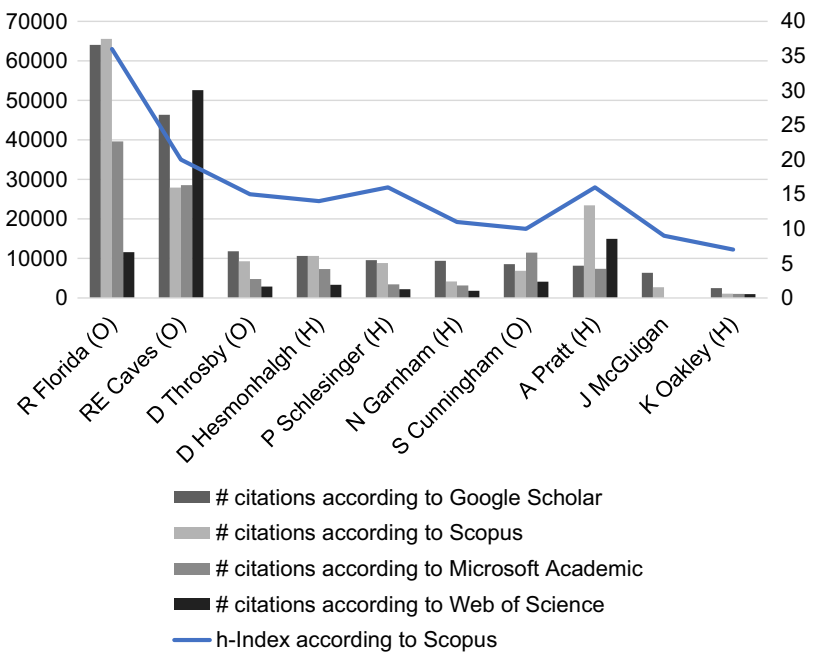

Fig. 2 Number of citations and "h-Index" for all the author's publications. Data collected in June 2018 from Google Scholar, Scopus, Microsoft Academic, and Web of Science.

researchers from the orthodox cluster), or from the heterodox cluster to criticize or respond to criticism (Cunningham strongly criticizes at least two of the heterodox researchers). These observations can be interpreted by linking them to the academic status of this researcher relatively to that of the other orthodox researchers: unlike Florida and Caves, Cunningham is among the moderately cited authors, but also among those with the lowest "h-Index" (see Fig. 2). Not having the same academic notoriety as the great passive authors, Cunningham appears more vehement in his criticism of heterodoxy, allowing him to nourish the visibility of his work.

Such observations confirm the specificity of the orthodox cluster since these positions of great passive (supported and criticized, but not supporting and not criticizing in return) and small active (citing and criticizing, but being poorly supported) are non-existent on the heterodox side. It can be postulated that, unlike orthodox scholars, the "marginal" position of heterodox scholars requires them to opt for strategies that allow them to collectively promote their work in the front of a cluster perceived as "dominant".

Polarization and disciplinary registration. A second dimension reinforces the structuring of the network of my sample into two clusters: disciplinary anchorage (see Table 7). Indeed, the more researchers enter a specialized field of work on the question of "culture" (regardless of the scientific department to which this specialty is subordinated: economics, political science or media and communication), the more likely they are to enter the heterodox cluster. Within the heterodox cluster, there is an overrepresentation of researchers (five out of six researchers) who, according to their job title, are involved in sub-disciplines associated with culture (in particular cultural policy studies). On the other hand, the orthodox cluster is over-represented by researchers (four out of five) from generalist disciplines (economics, management, business, creativity, media and communication) who do not mention the notion of "culture" in their titles. This can be associated with the fact that orthodox discourses on the "creative industries turn" imply a strong "decompartmentalization" of cultural activities and policies and their adaptation to innovation logics. This phenomenon of "despecialization" contributes to undoing the traditional categories of "culture", "cultural sector" or "cultural policy". 

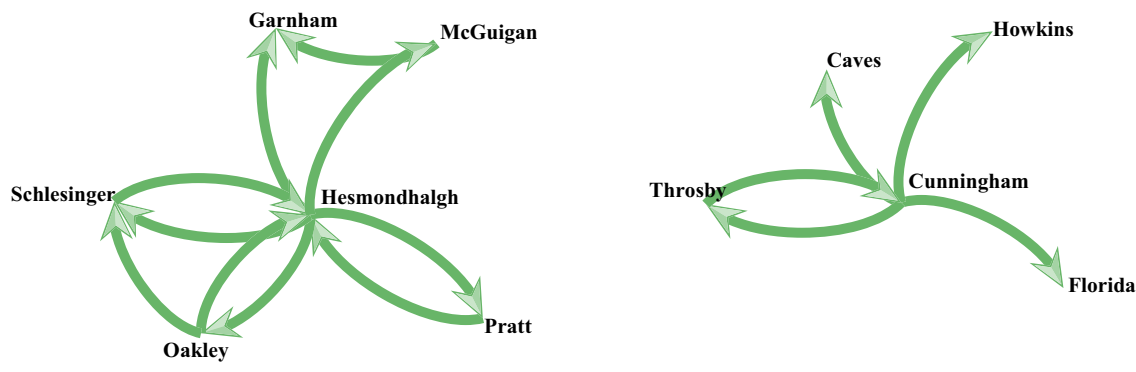

Fig. 3 Orientation of support citations. This shows the direction of supporting citations amongst the network.

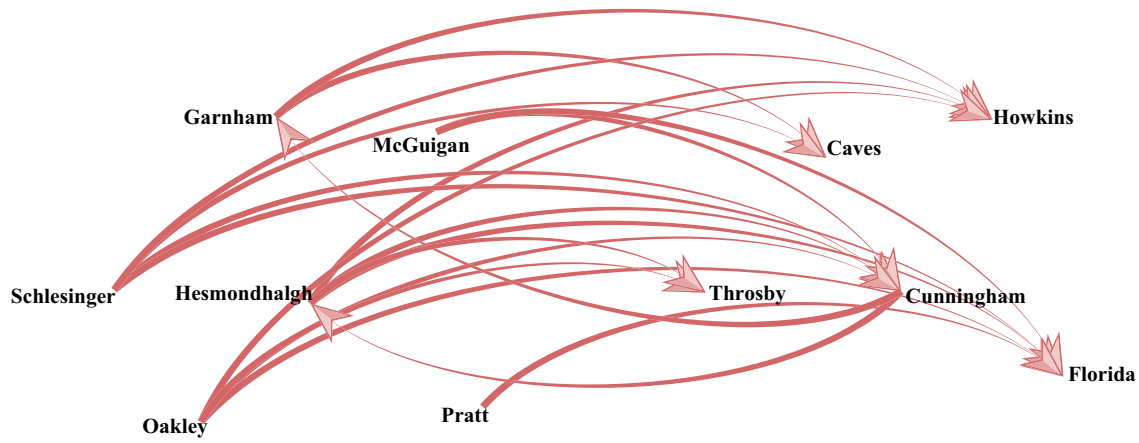

Fig. 4 Orientation of critical citations. This shows the direction of critical citations amongst the network.

\begin{tabular}{|c|c|}
\hline Authors & Discipline \\
\hline \multicolumn{2}{|l|}{ Heterodox cluster } \\
\hline Pratt Andy C. & Cultural economy \\
\hline OAKLEY Kate & Cultural policy \\
\hline SCHLESINGER Philip & Cultural policy \\
\hline GaRnHAM Nicholas & Media studies \\
\hline HeSMONDHALGH David & Media, Music and Culture \\
\hline McGUIGAN Jim & Cultural analysis \\
\hline \multicolumn{2}{|l|}{ Orthodox cluster } \\
\hline Richard E. CAVES & Economy \\
\hline CUNNINGHAM Stuart & Media and Communications \\
\hline HowKINS John & Management, Economy, Creativity \\
\hline THROSBY David & Cultural economy \\
\hline FLORIDA Richard & Economic analysis and Policy \\
\hline
\end{tabular}

Several cases allow us to refine this analysis in terms of disciplinary anchorage: most notably, David Throsby's, positioned rather on the orthodox side, but having a specialized disciplinary anchorage (economics of culture), and Nicholas Garnham, the only author amongst the heterodox cluster who is not a researcher in a sub-discipline that directly mentions the category of "culture". For his part, David Throsby, criticized by the heterodox cluster, is also frequently quoted in a neutral way many times from scholars of this cluster: my model reveals that he is the one who has the most links with the opposing cluster and who is the least criticized by it. He is, among orthodox scholars, the most eccentric researcher with regard to his own cluster. His specifically cultural anchorage, despite his orthodox position, goes hand in hand with the construction of less polarizing links with the heterodox cluster. This is confirmed by the case of Nicholas Garnham, Professor of Media studies (a discipline not specifically "cultural"), whose position among heterodox scholars is explained by the epistemological framework mobilized in his research: indeed, in all his writings, Nicholas Garnham claims an explicitly Marxian approach, which gives him a de facto heterodox position despite his disciplinary attachment.

Simultaneously, the lack of engagement of the great passive scholars can also be observed-on top of a "passive domination"-as a disciplinary rupture. Most orthodox academics see themselves as economists indistinctly attending to one of many economic sectors, and not interested or able to deal with the substance of specifically cultural disputes. As a matter of fact, Cunningham, who is the most likely to interact with the heterodox cluster, although in a critical manner, is also the only orthodox researcher who does not belong to the field of economics.

\section{Discussion}

This article suggests revisiting categories that are often taken for granted. Answering a call made by other researchers (Glötzl and Aigner, 2018), I attempted not to limit myself to a conceptual definition of the categories of orthodoxy and heterodoxy (i.e., a theoretical positioning that approaches or moves away from mainstream theories), but to define them looking at what those categories imply in practice. Indeed, I have chosen to treat the literature considering not only the theoretical proposals that emanate from it, but also the power relationship and the interactions that animate the field. This "relational" analysis allowed us to extend the results already found concerning the field of economics (Dobusch and Kapeller, 2012) to a growing field of study (that of research on the reform cultural policy). Shared observations concern the fact the heterodox versus orthodox binary can be observed as a "core-periphery pattern" (Cronin, 2010), meaning that the orthodox side represents a mandatory citation point for the members of the heterodox cluster (whereas the opposite is not true), suggesting that the orthodoxy indeed constitutes the center of a field inside which critical authors are the periphery. It simultaneously allowed us to show that researchers from the orthodox side do not act in a homogeneous 
manner. Depending on their visibility in the field, orthodox researchers may remain silent during the dispute, or instead frequently raise their voice to gain visibility (p. 15). I can thus affirm that specificities between clusters engender interactional specificities inside those clusters.

I argue that such an approach may help to think oppositions in a field of research, but also the possible continuities and circulation between orthodoxy and heterodoxy. As Davis argues, "a new orthodoxy might arise out of this new heterodoxy and traditional heterodoxy" (Davis, 2008). Indeed, further research shows that the opposition between orthodoxy and heterodoxy only momentarily corresponds to an opposition between specific political rationalities and forms of public action. Since theoretical elements of heterodoxy may, over time, gradually become appropriated by orthodoxy (and vice versa), it is of interest to researchers to build methods of categorization that look at the literature apart from the sole theoretical propositions they contain.

As a last resort, considering the literature apart from its sole content did not imply ignoring epistemological specificities in the corpus. On the contrary, it permitted to evaluate the weight of theoretical boundaries on the citation strategies available to the actors. In the case of the "creative industries turn" dispute, it appeared that the position of researchers in the network was also directly related to their department's discipline (p. 17). Actors evolving in a department which material existence depends on the perseverance of "culture" studies (as a specific and closed field of study), logically found themselves opposed to the "creative industries turn" of cultural policy which promotes to open borders of "culture" to the "creative economy". This approach thus allows to establish a concrete link between the categorical position of a researcher and disciplinary specificities.

I hope that this method can inspire research in other fields of investigation, to concretely characterize orthodox and heterodox positions.

\section{Conclusion}

In this article, I have shown that the dispute feeding the "creative industries turn" of cultural policy debate can be described as an opposition between two clusters. Several results were observed. First, the authors themselves express an opposition between orthodoxy and criticism, domination and resistance, neoliberalism and activism. Selfappointed critical authors oppose dominant proposals, while those with a dominant conception see themselves more as "non-political". Second, based on an analysis of citations between the researchers in my sample, I was able to highlight, through an attraction-repulsion model, the polarization of this network of authors. I have shown that the two clusters have a different internal structure: the orthodox cluster hosts great passive authors, strongly cited to be criticized or supported, but not citing their peers or little; conversely, the heterodox cluster is characterized by the absence of unilateral and passive relations and a high proportion of reciprocal intercitations. The orthodox cluster thus represents a mandatory citation passage point for the members of the heterodox cluster, which suggests that a part of the authors, whose paragon is Richard Florida, constitutes the center of a field of which critical authors are the periphery. The partition between orthodoxy and heterodoxy is also strongly correlated with the authors' disciplinary and sub-disciplinary registration.

At last, the article work concludes on the analytical possibilities brought by this relational approach. More importantly, this paper concludes that scientific dominance or political influence need not only to be explained as radical epistemological difference invoked by heterodox and orthodox positionality, but also by the interdependence of authors belonging to these categories. Overall, this paper aims to draw attention to a potential research agenda that uses a more dynamic understanding and categorization of heterodoxy and orthodoxy.

\section{Data availability}

The dataset analyzed during the current study is derived from the bibliography cited in the first two sheets of the Appendix. The third sheet is the result of an intercitation review directly from this bibliography.

Received: 27 January 2020; Accepted: 20 October 2020; Published online: 13 November 2020

\section{Notes}

1 In mobilizing the notion of justification, I explicitly refer to the idea, developed by Luc Boltanski and Laurent Thévenot in De la justification (Boltanski and Thévenot, 2006), that the social order "stands" because of an imperative of justification "on which rests the possibility of coordination of human behavior". In their work, Boltanski and Thévenot formalize systems of shared equivalences-which they call "grammars"allowing the actors of the social world to find forms of agreement, whatever the situation. They thus developed a series of "cities" that can be described as grammatical sets, or conventions, recognizable by interacting individuals. This interpretation in terms of normative frameworks for public action may be reminiscent at certain points of the notions of "referentials" (Muller, 1995) or "paradigms" (Hall, 1993), to which many works in political science are attached, particularly those claiming to be the "cognitive analysis" of public policies. Indeed, for Muller, "from the moment that the object of public policies is no longer simply to 'solve problems', but to construct frameworks for interpreting the world, then it is possible to ask the question of the relationship between policy(s) and the construction of a social order in renewed terms" (Muller 2000, p. 189).

2 In this regard, I would like to thank Justin O'Connor for his extensive literature review. 3 I, for example, excluded the director of the Nesta consulting agency, Hasan Bakhshi, whose name appears in several bibliographies and literature reviews.

4 This is also the case for John Howkins whose position as a great passive is not so explicit: this can be explained by the fact that despite his status as a visiting professor in at least two universities, John Howkins belatedly joined the academia. His major book, The Creative Economy: How People Make Money from Ideas, is nevertheless systematically cited in the literature, supported (see Fig. 3) and particularly criticized (see Fig. 4).

\section{References}

Angermuller J, Hamann J (2019) The celebrity logics of the academic field. The unequal distribution of citation visibility of Applied Linguistics professors in Germany, France, and the United Kingdom. Z Diskursforsch 1(2019):77-93

Arfaoui M (2019) «Creative Europe» ou l'action publique par projet. Enquête sur une modernisation des politiques publiques en Europe. Doctoral dissertation, EHESS-Paris

Balmer JMT, Johansen TS, Nielsen AE (2016) Scrutinizing stakeholder thinking: orthodoxy or heterodoxy?. Int Stud Manag Organ 46(4):205-215

Banks M, O'Connor J (2017) Inside the whale (and how to get out of there): Moving on from two decades of creative industries research. Eur J Cult Stud 20(6):637-654

Bennett O (2004) The Torn Halves of cultural policy research. Int J Cult Policy 10 (2):237-248

Bennett T (1998) Culture: a reformer's science. SAGE Publications Inc, London; Thousand Oaks, p. 272

Benghozi P-J, Paris T (2016) The cultural economy in the digital age: a revolution in intermediation?. City Cult Soc 7(2):75-80

Bernard LL (1935) The great controversey; or, both heterodoxy and orthodoxy in sociology unmasked. Soc Forces 14:64

Bögenhold D (2010) From heterodoxy to orthodoxy and vice versa: economics and social sciences in the division of academic work. Am J Econ Sociol 69 (5):1566-1590

Boltanski L, Thévenot L (2006) On justification: economies of worth. Princeton University Press, Princeton, p. 408

Bouquillion P, Miège B, Moeglin P (2009) La question des industries créatives en France. Econ Cult 19(1):35-48

Bourdieu P (2001) Science de la science et réflexivité: cours du Collège de France, 2000-2001. Raisons d'agir (coll. "Collection "Cours et travaux"»), Paris, p. 237

Bourdieu P (1994) "Structures, habitus, power: basis for a theory of symbolic power" dans culture/power/history: a reader in contemporary social theory. Princeton University Press, Princeton, pp. 155-199

Calhoun C, van Antwerpen J (2007) “Orthodoxy, heterodoxy, and hierarchy: "mainstream" sociology and its challengers" dans. In: Calhoun Craig (ed.) Sociology in America: a History. University of Chicago Press, Chicago, pp. $367-410$ 
Carpintero Ó (2013) When heterodoxy becomes orthodoxy: ecological economics in the New Palgrave Dictionary of Economics. Am J Econ Sociol 72 (5):1287-1314

Caves RE (2000) Creative industries: contracts between art and commerce. Harvard University Press, Cambridge, p. 472

Cronin B (2010) The diffusion of heterodox economics. Am J Econ Sociol 69 (5):1475-1494

Cunningham S (2009) Trojan horse or Rorschach blot? Creative industries discourse around the world. Int J Cult Policy 15(4):375-386

Cunningham S, John H, Paul O, Jason P (2008) Social network markets: a new definition of the creative industries. J Cult Econ 32(3):167-185

Davis JohnB (2008) The turn in recent economics and return of orthodoxy. Camb J Econ 32(3):349-366

Dobusch L, Kapeller J (2012) Heterodox united vs. mainstream city? Sketching a framework for interested pluralism in economics. J Econ Issues 46 (4):1035-1058

Flew T, Cunningham S (2010) Creative industries after the first decade of debate. Inf Soc 26(2):113-123

Florida R (2002) The rise of the creative class: and how it's transforming work, leisure, community and everyday life. Basic Books, New York, p. 434

Glötzl F, Aigner E (2018) Orthodox Core-Heterodox periphery? Contrasting citation networks of economics departments in Vienna. Rev Political Econ 30 (2):210-240

Gunnell JG (2006) Political science: orthodoxy and heterodoxy. Good Soc 15 (1):21-25

Hall PA (1993) Social learning, and the state: the case of economic policy making in Britain. Comp Politics 25(3):275-296

Harney S (2010) Creative industries debate: unfinished business: labour, management, and the creative industries. Cult Stud 24(3):431-444

Hesmondhalgh D (2008) "Cultural and creative industries" dans. In: Bennett Tony, Frow John (eds.) The Sage handbook of cultural analysis. Sage, Los Angeles, pp. $552-569$

Hesmondhalgh D, Banks M (2009) Looking for work in creative industries policy. Int J Cult Policy 15(4):415-430

Hesmondhalgh D, Nisbett M, Oakley K, Lee D (2014) Were New Labour's cultural policies neo-liberal? Int J Cult Polic 1-18

KEA European Affairs (2009) The impact of culture on creativity. KEA European Affairs

KEA European Affairs (2006) The economy of culture in Europe. KEA European Affairs. http://ec.europa.eu/assets/eac/culture/library/studies/cultural-economy_en.pdf

Lake P (2001) The Boxmaker's revenge: «orthodoxy», «heterodoxy», and the politics of the Parish in early Stuart London. Manchester University Press, Manchester, p. 440

Lee FS, Elsner W (2008) Publishing, ranking, and the future of heterodox economics. On Horiz 16(4):176-184

Lixinski L (2015) Between orthodoxy and heterodoxy: the troubled relationships between heritage studies and heritage law. Int J Heritage Stud 21(3):203-214

McGuigan J (2016) Neoliberal culture. Palgrave Macmillan, London, p. 249

McGuigan J (2005) Neo-liberalism, culture and policy. Int J Cult Policy 11 (3):229-241

Miège B, Moeglin P, Bouquillion P (2013) L'industrialisation des biens symboliques. Les industries créatives en regard des industries culturelles. Presses Universitaires de Grenoble, Grenoble, p. 252

Muller P (2000) «L'analyse cognitive des politiques publiques: vers une sociologie politique de l'action publique». Revue Fr Sci Politique 50(2):189-208

Muller P (1995) «Les politiques publiques comme construction d'un rapport au monde » dans La construction du sens dans les politiques publiques. Débats autour de la notion de référentiel. L'Harmattan, Paris, p. 192

Oakley K (2006) Include us out-economic development and social policy in the creative industries. Cult Trends 15(4):255-273
Oakley K (2004) Not so cool Britannia: the role of the creative industries in economic development. Int J Cult Stud 7(1):67-77

O'Connor J (2007) The cultural and creative industries: a review of the literature: a report for Creative Partnerships. Creative Partnerships, Arts Council England, London

Pratt AC (2005) Cultural industries and public policy. Int J Cult Policy 11(1):31-44

Rinck F (2010) «L'analyse linguistique des enjeux de connaissance dans le discours scientifique». Rev Anthropol Connaiss 4(3):427-450

Rosen S (1981) The economics of superstars. Am Econ Rev 1981:845-858

Sangren PS (1987) Orthodoxy, heterodoxy, and the structure of value in Chinese rituals. Modern China 13(1):63-89

Schlesinger P (2016) The creative economy: invention of a global orthodoxy. Innovation 30(1):73-90

Schlesinger P (2013) Expertise, the academy and the governance of cultural policy. Media Cult Soc 35(1):27-35

Schlesinger P (2009) Creativity and the experts: new labour, think tanks, and the policy process. Int J Press/Politics 14(1):3-20

Simon U, Langer R (2008) The dynamics of orthodoxy and heterodoxy. dealing with divergence in muslim discourses and islamic studies. Die Welt Islams 48 (3):273-288

UNCTAD (2008) Creative economy report 2008: the challenge of assessing the creative economy: towards informed policy-making. United Nations, New York

Wang J (2016) The global reach of a new discourse. Int J Cult Stud 7(1):9-19

Wardwell W (1972) Orthodoxy and heterodoxy in medical practice. Soc Sci Med 6 (759):63

Wilson MB (2009) The failure of nomenclature: the concept of "Orthodoxy" in the study of Islam. Comp Islam Stud 3, 2

\section{Competing interests}

The author declares no competing interests.

\section{Additional information}

Supplementary information is available for this paper at https://doi.org/10.1057/s41599 020-00637-1.

Correspondence and requests for materials should be addressed to M.A.

Reprints and permission information is available at http://www.nature.com/reprints

Publisher's note Springer Nature remains neutral with regard to jurisdictional claims in published maps and institutional affiliations.

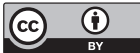

Open Access This article is licensed under a Creative Commons Attribution 4.0 International License, which permits use, sharing, adaptation, distribution and reproduction in any medium or format, as long as you give appropriate credit to the original author(s) and the source, provide a link to the Creative Commons license, and indicate if changes were made. The images or other third party material in this article are included in the article's Creative Commons license, unles indicated otherwise in a credit line to the material. If material is not included in the article's Creative Commons license and your intended use is not permitted by statutory regulation or exceeds the permitted use, you will need to obtain permission directly from the copyright holder. To view a copy of this license, visit http://creativecommons.org/ licenses/by/4.0/

(c) The Author(s) 2020 